\title{
RELATIONSHIP BETWEEN THE ABUNDANCE OF APHIDS AND THEIR NATURAL ENEMIES IN CEREAL FIELDS AND LANDSCAPE COMPOSITION
}

\author{
DIAB AL HASSAN ${ }^{1, *}$, NICOLAS PARISEY ${ }^{2}$, FRANCCOISE BUREL ${ }^{1}$, \\ MANUEL PLANTEGENEST ${ }^{2}$, PAVEL KINDLMANN ${ }^{3}$, and ALAIN BUTET ${ }^{1}$ \\ ${ }^{1}$ CAREN-OSUR, UMR CNRS 6553 Ecobio, Université de Rennes 1, Avenue Général Leclerc, 35042 Rennes cedex, France. \\ Tel.: +332232366 63; Fax: +33223235026 \\ 2 UMR INRA Agrocampus Rennes 1099 BIO3P, 65, rue de Saint Brieuc, CS 84215, 35042 Rennes, France \\ 3 Department of Biodiversity Research, Global Change Research Center AS CR, Na Sádkách 7, 37005 České Budějovice, \\ and Institute for Environmental Studies, Charles University, Benátská 2, 12801 Prague 2, Czech Republic \\ * Corresponding author: dyabhasan@hotmail.com
}

\begin{abstract}
We investigated, over the course of two years, the association between the abundance of aphids and their natural carabid enemies and landscape, which may help in the development of effective strategies for reducing the incidence of aphid outbreaks in agricultural crops. This was undertaken in 12 wheat and 12 maize fields each year in an agricultural landscape in western France. Our study area was characterized by hedgerows surrounding arable fields and permanent grassland. Some areas have not changed much for several decades, while field enlargement and removal of hedges occurred in some areas following agricultural intensification. This paper aims to determine if the abundance of aphids in crops (either directly, or indirectly via their natural enemies) is associated with the landscape around fields and if so, is it dependent on the landscape scale considered. We observed that the abundance of aphids in fields was associated with landscape composition at a large scale $(500 \mathrm{~m}$ and $800 \mathrm{~m})$. There was a positive correlation between the abundance of aphids and the proportion of the area under woodland and grassland at these scales. There was a negative correlation between the abundance of carabids and the proportion of grassland and hedgerow around crop fields. The species richness of carabids was positively correlated with the proportion of hedgerows. We found that the abundance of aphids in wheat fields was negatively and in maize fields positively associated with the proportion under grass strips. At a large scale carabid abundance in both types of culture was positively correlated with the proportion under grass strips.
\end{abstract}

Keywords: agroecosystems, landscape structure, crop pests, aphids, biological control, semi-natural habitats

\section{Introduction}

The increasing demand of the human population for food resulted in the necessity to increase agricultural yields and subsequently in the intensification of agriculture (Gardner 1996; Krebs et al. 1999), which among other things resulted in an increasing use of pesticides (Lewis et al. 1997; Oerke and Dehne 2004; Ameixa and Kindlmann 2011a). However, the use of pesticides has not completely prevented pest outbreaks and subsequent losses of yield (Wilson et al. 2001; Oerke 2006), because the pests have either become resistant to pesticides and/ or there has been a breakdown in ecological processes like pollination, ecological functioning of the soil and biological control (Lewis et al. 1997; Plantegenest et al. 2007). In addition, there are many reports of pesticides adversely affecting man (Benton 2003; Lee 2004; Ameixa and Kindlmann 2011a). Therefore, effective alternatives to pesticides have to be found.

One alternative is to use ecosystem services, such as natural enemies, to suppress the abundance of agricultural pests (Kindlmann and Růžička 1992; Altieri 1999; Kindlmann and Dixon 1999; Plantegenest et al. 2001; Benton 2003; Wratten et al. 2003). In this respect landscape complexity, both in terms of composition and structure can be important (Burel and Baudry 1995; Kindlmann et al. 2005). Agricultural intensification leads to simplification of landscape structure by increasing the size of the fields, homogenization of cultures and fragmentation of semi-natural habitats (hedges, grasslands, woodlands), which has resulted in a reduction in the biodiversity in agroecosystems, including that of natural enemies, (Stoate et al. 2001; Robinson and Sutherland 2002). This undermines the efficiency of natural biological control at a local and landscape scale (Östman 2001; Krauss 2011), because regulation of pests by their natural enemies is more likely in a heterogeneous landscape ( $\mathrm{Bi}$ anchi et al. 2006; Maisonhaute and Lucas 2012). This is also supported by a meta-analysis of the results published in 209 papers, which shows that $52 \%$ of herbivorous insects are significantly less abundant in polycultures than in monocultures (Andow 1991).

Aphids (Hemiptera: Aphididae) are among the most important pests globally (Dixon et al. 1996; Dixon and Kindlmann 1998; van Emden and Harrington 2007; Ameixa and Kindlmann 2011b; Šipoš et al. 2012). They are harmful to crops because they both consume phloem sap and thus deprive plants of nutrients (Fievet et al. 2007; Giordanengo et al. 2007), and are vectors of viruses, which can seriously damage plants (Nault et al. 1997).

Non-flying polyphagous generalist predators, like carabids, are important natural enemies of aphids. It is believed that predation by carabids can regulate aphid abundance and reduce the incidence of outbreaks (Symondson et al. 2002). However, their regulatory effect on aphids is still not fully understood, because it is rarely 
studied in the field and the composition of the diet of carabids is not well known (Holland 2002; Symondson et al. 2002; Sunderland 2003; Ameixa and Kindlmann 2008).

Landscape composition, in terms of the relative proportion and size of patches of vegetation of different types and their spatial configuration, is important for both aphids and carabids. Because of their poor dispersal ability, many species of carabids are very sensitive to landscape fragmentation and changes in land use (Petit and Burel 1998; Holland 2002; Keller and Largiadèr 2003). The presence and abundance of aphids in crops is also associated with the structure of the landscape (Ricci et al. 2009). This is because both aphids and their natural enemies do not overwinter in fields but in semi-natural habitats such as woodland and grassland (Carter et al. 1982; Corbit et al. 1999; Pywell et al. 2011). These habitats provide a source of both aphids and their natural enemies, which colonize cereal fields in spring (Winder et al. 1999; Levie et al. 2005; Martinez et al. 2005; Bianchi et al. 2006; Grez et al. 2008). Therefore, the effect of seminatural habitats on aphid abundance can be both positive and negative, depending on relative abundance of aphids and their natural enemies in the semi-natural habitats (Vanbergen et al. 2010; Vandewalle et al. 2010; Woodcock et al. 2010).

The aim of this study is to determine the association between the abundance of aphids and their natural enemies and landscape, which may help in the development of effective strategies for reducing the incidence of aphid outbreaks in agricultural landscapes. Here we test the hypothesis that the abundance of aphids in fields is influenced by landscape composition (either directly, or indirectly via their natural enemies) and this is dependent on the landscape scale considered.

\section{Materials and methods}

\section{Study site}

This study was conducted during 2009 and 2010 within an agricultural landscape situated in the "ZA Armorique" in the vicinity of Pleine-Fougères, which is located in the south of Mont Saint Michel's Bay (Brittany, Western France, $\left.48^{\circ} 36^{\prime} \mathrm{N}, 1^{\circ} 32^{\prime} \mathrm{W}\right)$. The locality is a long-term ecological research site (Burel et al. 1998; Baudry et al. 2000). It is representative of the "bocage" landscape, characteristic for Brittany, with a mixture of cultivated fields and grassland with a dense network of hedges (Baudry et al. 2000). This site also has a gradient of landscapes (Fig. 1) ranging from a fine-grain landscape with a complex network of hedgerows ( $160 \mathrm{~m} / \mathrm{ha}$ ) enclosing small fields and a heterogeneous landscape structure (Le Coeur et al. 1997) to a more open landscape with fewer meters of hedgerow per hectare $(70 \mathrm{~m} / \mathrm{ha})$ enclosing large fields (Baudry et al. 2000). The main crops in this area are ce- reals, maize, oilseed rape and vegetables. The main agricultural activity is mixed farming and milk production.

To estimate the variations in the landscape at the scale of this area, the experimental fields were chosen within an area of $24 \mathrm{~km}^{2}$, distributed along the landscape gradient in each year (Baudry et al. 2006), depending on the features of the surrounding landscape. The software CHLOETM 3.1 and ZAZIETM1.0 (Baudry et al. 2006) was used to verify that the fields were representative of the gradient in openness of the landscape within the study area.

\section{Monitoring}

In each year (2009 and 2010), 12 wheat and 12 maize fields were chosen at random within the experimental area (because of crop rotation they differed between years). In each of these fields, six sampling points were randomly selected using ArcGIS software (version 9.1, ESRI) and geo-referenced using a GPS (Juno ${ }^{\mathrm{TM}}$ ST, Software ArpentGIS 4.5). In each year, sampling was performed 5 times during the season for wheat and 6 times for maize fields, every 2 weeks: between May 1 and July 15 in wheat and June 20 and September 5 in maize fields. This period covers the time when aphids are most abundant on these crops.

At each of these points and instants, the numbers of aphids present on 25 tillers of wheat and 5 plants of maize were counted and their species and developmental stages and life form (larvae, unwinged and winged adults) were determined. Carabids were captured at the same sampling points, using pitfall traps (one trap per sampling point). Each trap was set when the aphids were counted and emptied 15 days later. The traps (polypropylene pots, $\mathrm{H}=120 \mathrm{~mm}, \varnothing 8.5 \mathrm{~cm}$ ) were buried in the ground and protected from rain by transparent plexiglas plates, positioned about two inches above each trap. Each trap contained a solution of $50 \%$ salt water and $50 \%$ propylene glycol (Bouget 2001). Captured carabids were stored in $70 \%$ alcohol and identified to the species level using the identification keys of Trautner and Geigenmüller (1987) and Forsythe (2000).

\section{Characterization of the landscape}

In a $100 \mathrm{~m}$ wide buffer strip around each field and in circles with diameters 300,500 , and $800 \mathrm{~m}$, centered in the centre of each the fields sampled, we measured six variables: percentage of land covered by (1) grassland, (2) woodland, (3) grass strips, (4) crops (wheat, maize, oilseed rape), (5) other elements (water, builtup areas, roads, railways, gardens) and the length in meters of (6) hedgerows. All these were identified and digitized with ArcGIS software (version 9.1, ESRI). In the subsequent text, the distance is indicated as a subscript to the landscape variable (e.g., grassland ${ }_{800}$ means proportion of grassland in the circle with $800 \mathrm{~m}$ diameter). The distances used are a compromise between the scale to which the 


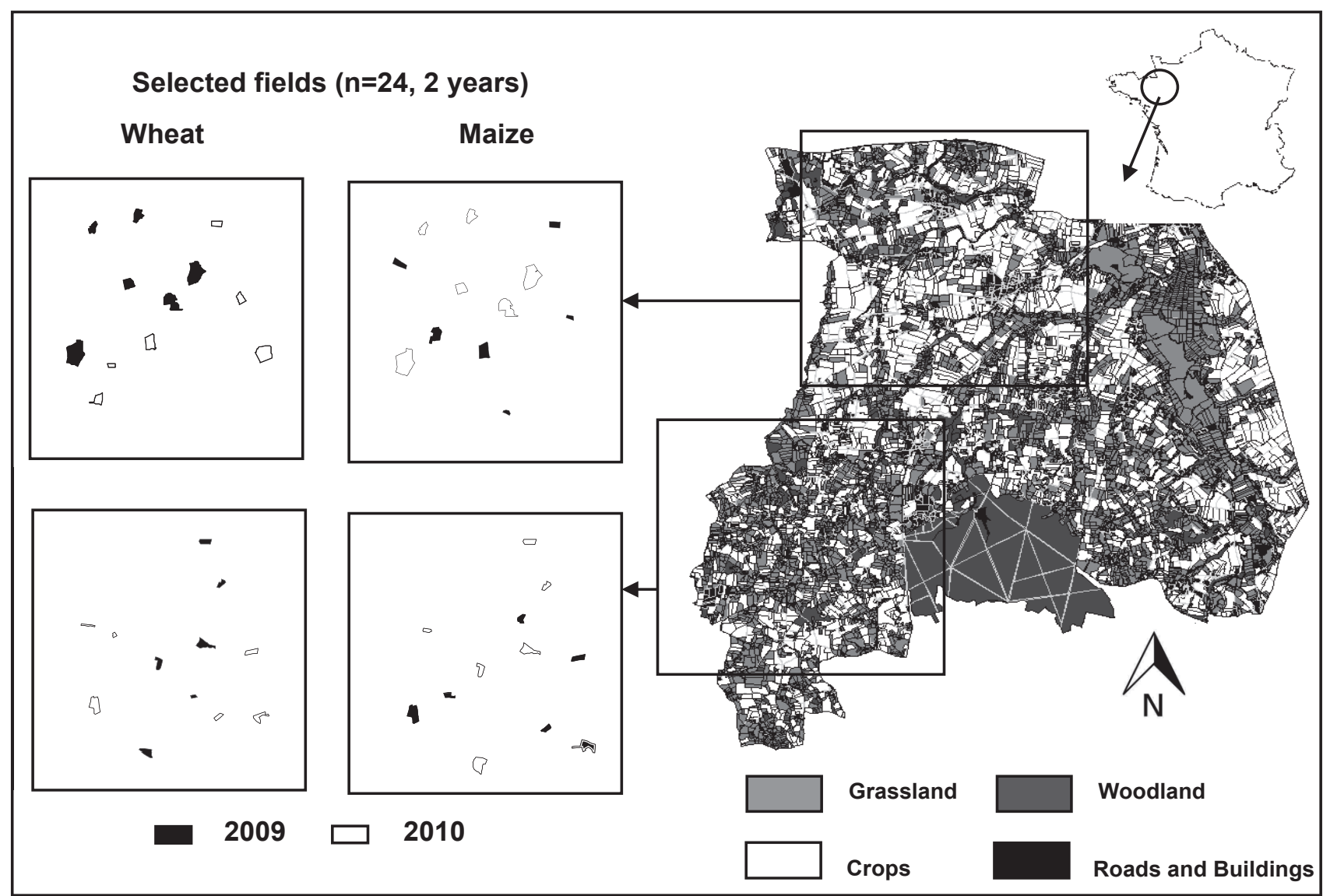

Fig. 1 Location and main land use in the study area. Distribution of the 24 wheat and maize fields sampled in the two years of the study.

landscape structure influences the maximum population of aphids and parasitoids: about $1 \mathrm{~km}$ (Rand and Tscharntke 2007). The hedgerows were included, because they structure agricultural landscapes and thus are particularly important with respect to the movement of organisms in agroecosystems (Ricci et al. 2009).

The abundance of aphids is determined by climatic factors (Hulle et al. 2010), and therefore we also included year as an explanatory variable. As we considered percentages, we had only 5 degrees of freedom among the 6 variables and one of them could be deleted. Because the percentage covered by grassland was strongly negatively correlated with that of the cultures, we deleted cultures from further analyses. This resulted in 21 variables: 5 types of landscape times 4 sizes of circles/buffer zones considered, plus year.

\section{Statistical analysis}

Because the number of explanatory variables was large, we had to adopt a procedure for variable selection. This was conducted in two phases. First, we used a procedure for selecting variables used by Ricci et al. (2009). For each landscape variable and each distance, the Akaike index (Akaike Information Criterion, Akaike 1974) was calculated. The distance with the lowest AIC was selected for subsequent analyses. Then, the procedure glmulti (Calcagno and De Mazancourt 2010) was applied to select the combination of variables producing the best model based on the AIC values. The default method in glmulti $(\operatorname{method}=$ "h") fits all candidate models. All 50 possible models containing all considered explanatory factors were fitted to the data and ranked according to their AIC values from the model with the lowest AIC value (Appendices 1, 2, 3, and 4). Top regression models, with the highest level of empirical support, were those within AIC units of the top-supported model (Burnham and Anderson 2002) and with informative parameters (Arnold 2010). Finally, the GLM including all variables selected by this procedure were adjusted to the data set. All data were pooled and analyses used Poisson error term and a Log link. The significance of the estimated parameters was tested using the chi-square test. These models were calculated using R Software (R Development Core Team, 2008).

Autocorrelation is problematic for classical statistical tests like regression, which rely on independently distributed errors (Legendre 1993), as it may lead to erroneous conclusions regarding the significance of covariates in studies of species-environment relationships (Christman 2008; Thornton et al. 2011). To account for this, the coordinates of each field were obtained using ArcGIS software ${ }^{\circledR}$ and used for subsequent tests of spatial autocorrelation between fields (Thébaud et al. 2006). In order to test for spatial autocorrelation of the residuals of the best model (GLM) for total aphid and carabid abundances in the field, we computed Moran's I indices for nearest-neighbour pairs of the fields sampled according 


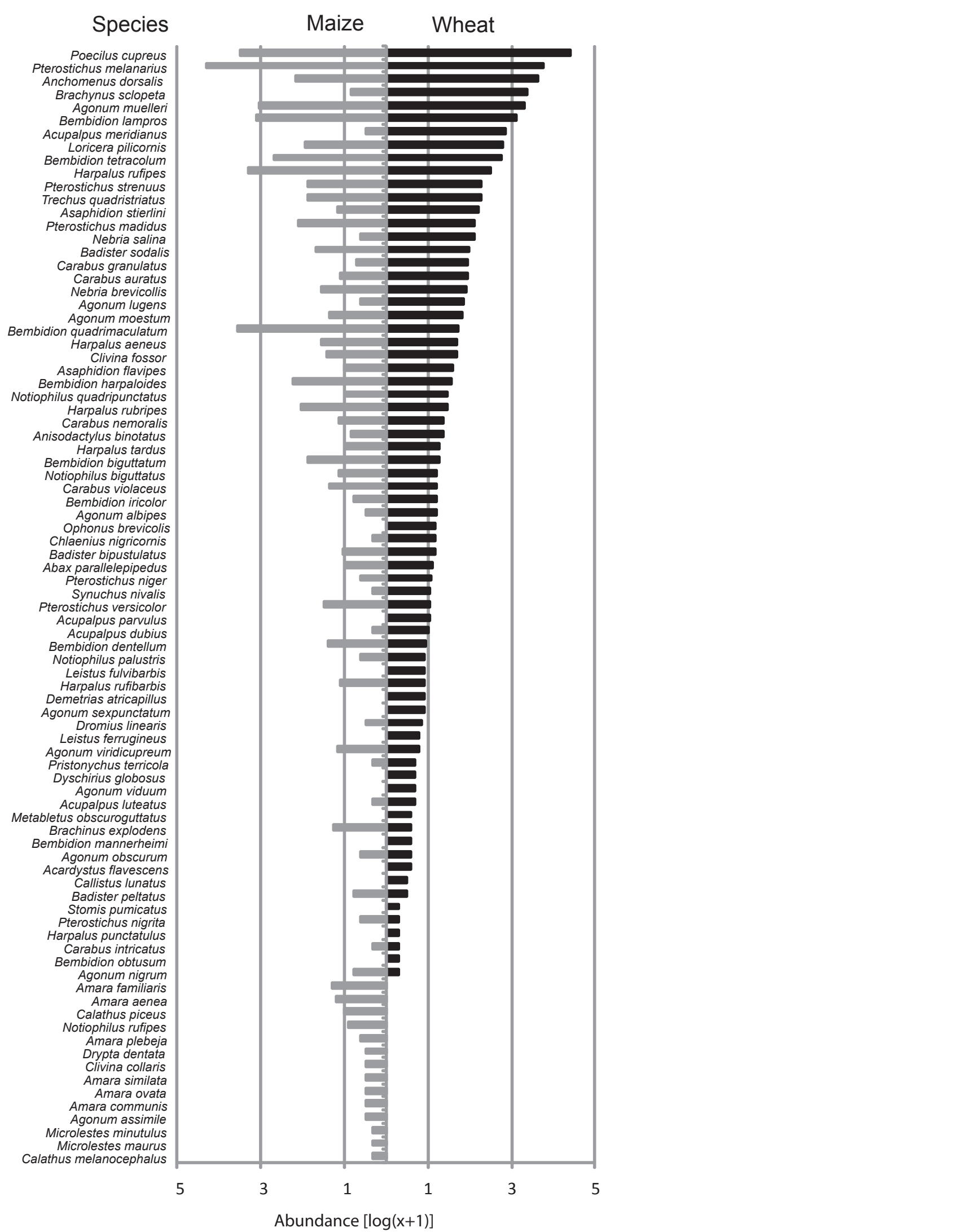

Fig. 2 Rank abundance distribution of carabid species in wheat and maize fields. Only species recorded in wheat fields are ranked.

to the Delaunay network. The objective was to test the interdependence of the residuals of the model within our area. Under the hypothesis of spatial independence, the values of the residuals should be distributed at random among the locations of the coordinates of the fields sampled (Thébaud et al. 2006). Spatial autocorrelation was tested using Passage 2.0 software (Rosenberg 2009). The significance of the coefficients of autocorrelation was tested against the null hypothesis of absence of a spatial arrangement $(\alpha=0.05)$. 


\section{Results}

We recorded a total of 40,167 aphids in the wheat fields and 31,125 in the maize fields. In Western Europe, Sitobion avenae, Metopolophium dirhodum and Rhopalosiphum padi (Homoptera: Aphididae) are the three most abundant cereal aphid pests (Carter et al. 1982; Hill 1987). However, in this study, all three species were found only in maize fields: $S$. avenae (11,450 individuals), M. dirhodum (5250) and R. padi $(14,425)$, but only $S$. avenae $(31,897)$ and $M$. dirhodum (8270) were found in wheat fields. A total of 85 species of carabid were captured: 44,558 individuals of 71 species in wheat fields and 32,148 of 70 species in maize fields. The two crops shared 56 species. Rank-abundance values for all the species found in wheat and maize fields are plotted in Fig. 2.

\section{The association between abundance of aphids in wheat fields and landscape}

The model that best described total aphid and S. avenae abundances, included year, woodland ${ }_{800}$, grassland $_{300}$, grass strips ${ }_{800}$, and hedgerow ${ }_{800}$ for total abundance of aphids and year, woodland ${ }_{800}$, grassland $_{300}$, grass strips $_{800}$, and hedgerow $\mathrm{w}_{100}$ for $S$. avenae. The model that best described the abundance of $M$. dirhodum included year, grassland ${ }_{100}$, grass strips ${ }_{300}$, and hedgerow $_{500}$ (see AIC values of the generalized linear model, Appendix 1).

The best models for total abundance and that of each aphid species in wheat fields are presented in Table 1. Estimated parameter values indicate that there are positive associations between total aphid abundance and woodland ${ }_{800}$ and grassland ${ }_{300}(\chi 2=5038.7 ; \mathrm{df}=1$, $P<0.0001, \chi 2=3380.6 ; \mathrm{df}=1, P<0.0001$, respectively) and that of $S$. avenae $(\chi 2=5974.9 ; \mathrm{df}=1, P<0.0001$, $\chi^{2}=1943.7 ; \mathrm{df}=1, P<0.0001$, respectively). The abundance of $M$. dirhodum was positively correlated only with grassland ${ }_{100}\left(\chi^{2}=66.103 ; \mathrm{df}=1, P<0.0001\right)$. The total aphid abundance was significantly negatively correlated with grass strips 800 and hedgerow 800 $\left(\chi^{2}=3684.2 ; \mathrm{df}=1, P<0.0001, \chi^{2}=206.18 ; \mathrm{df}=1\right.$, $P<0.0001$, respectively) as was that of $S$. avenae with grass strips $_{800}$ and hedgerow ${ }_{100}(\chi 2=3432.8 ; \mathrm{df}=1$, $P<0.0001, \chi 2=1292.3 ; \mathrm{df}=1, P<0.0001$, respectively) and $M$. dirhodum with grass strips ${ }_{300}$ and hedgerow ${ }_{500}$ $\left(\chi 2=61.067 ; \mathrm{df}=1, P<0.0001, \chi^{2}=54.613 ; \mathrm{df}=1\right.$, $P<0.0001$, respectively). The year did not contribute significantly to explaining total aphid and species' abundances of aphids in wheat fields $(\chi 2=419.52 ; \mathrm{df}=1$, $P=0.0799, \chi^{2}=122.26 ; \mathrm{df}=1, P=0.0887, \chi^{2}=41.1$; $\mathrm{df}=1, P=0.1147$, respectively).

The analysis revealed no spatial autocorrelation for the model residuals (GLM) of total aphid abundance at the level of the 12 fields sampled each year; aphids in 2009: $\mathrm{I}=-0.18, \mathrm{p}=0.55$; aphids in 2010: $\mathrm{I}=-0.014$, $p=0.61$. This means that the residuals exhibit no spatial structure and the fields sampled can be considered as independent spatial replicates.

\section{The association between total abundance and species richness of carabids in wheat fields and landscape}

The best model describing total abundance of carabids included year, grassland ${ }_{800}$, other ${ }_{300}$, grass strips ${ }_{800}$, and hedgerow $_{800}$. The best model describing species richness of carabids included other ${ }_{300}$, and hedgerow ${ }_{800}$ (see AIC values of the generalized linear model, Appendix 2).

The best models for total abundance and species richness of carabids in wheat fields are presented in Table 2. The total abundance of carabids was negatively associated with grassland $_{800}$, and hedgerow ${ }_{800}$ $\left(\chi 2=94.165 ; \mathrm{df}=1, P<0.0001, \chi^{2}=9.8548 ; \mathrm{df}=1\right.$, $P=0.001694$, respectively). There was a significant positive correlation between the total abundance of carabids and grass strips ${ }_{800}$ and other ${ }_{300}(\chi 2=853.46$; $\left.\mathrm{df}=1, P<0.0001, \chi^{2}=470.51 ; \mathrm{df}=1, P<0.0001\right)$. The species richness of carabids was positively associated with the proportion covered by hedgerow ${ }_{800}(\chi 2=6.3529$; $\mathrm{df}=1, P=0.001742)$. In the wheat fields, no association between species richness of carabid and the proportion of other was detected $(\chi 2=4.3555 ; \mathrm{df}=1, P=0.05689)$.

The analysis revealed no spatial autocorrelations in the residuals of the model (GLM) for carabid abundance at the level of the12 fields sampled each year; carabids in 2009: $\mathrm{I}=0.154, \mathrm{p}=0.09$; carabids in 2010: $\mathrm{I}=-0.005$, $\mathrm{p}=0.56$. This means that the residuals exhibit no spatial structure and the fields sampled can be considered as independent spatial replicates.

\section{The association between abundance of aphids in maize fields and landscape}

The best model describing total abundance of aphids included woodland $d_{300}$, other ${ }_{500}$, grass strips ${ }_{300}$, hedgerow $_{800}$, and grassland ${ }_{800}$. The best model describing the abundance of $S$. avenae included hedgerow ${ }_{800}$, grassland $_{800}$, woodland ${ }_{500}$, and grass strips ${ }_{800}$. The best model describing the abundance of $M$. dirhodum included grassland ${ }_{800}$, grass strips $s_{500}$, and hedgerow ${ }_{100}$. For the abundance of $R$. padi, the best model included woodland $_{300}$, grass strips 300 , and grassland ${ }_{500}$ - see AIC values of the generalized linear model, Appendix 3.

The best models for total abundance and that of each aphid species in maize fields are presented in Table 3. We found that the total abundance of aphids was positively associated with woodland ${ }_{300}$, other ${ }_{500}$, grass strips ${ }_{300}$, and grassland $\mathrm{g}_{800}(\chi 2=1082.7 ; \mathrm{df}=1, P<0.0001$, $\chi 2=1397.4 ; \mathrm{df}=1, P<0.0001, \chi 2=1559.1 ; \mathrm{df}=1, P<0.0001$, $\chi^{2}=1125.9 .1 ; \mathrm{df}=1, P<0.0001$, respectively), and $S$. avenae abundance positively with grassland $_{800}$ woodland $_{500}$, and grass strips ${ }_{800}$ $\left(\chi^{2}=220.72 ; \mathrm{df}=1, P=0.00410, \chi^{2}=14.45 ; \mathrm{df}=1\right.$, 


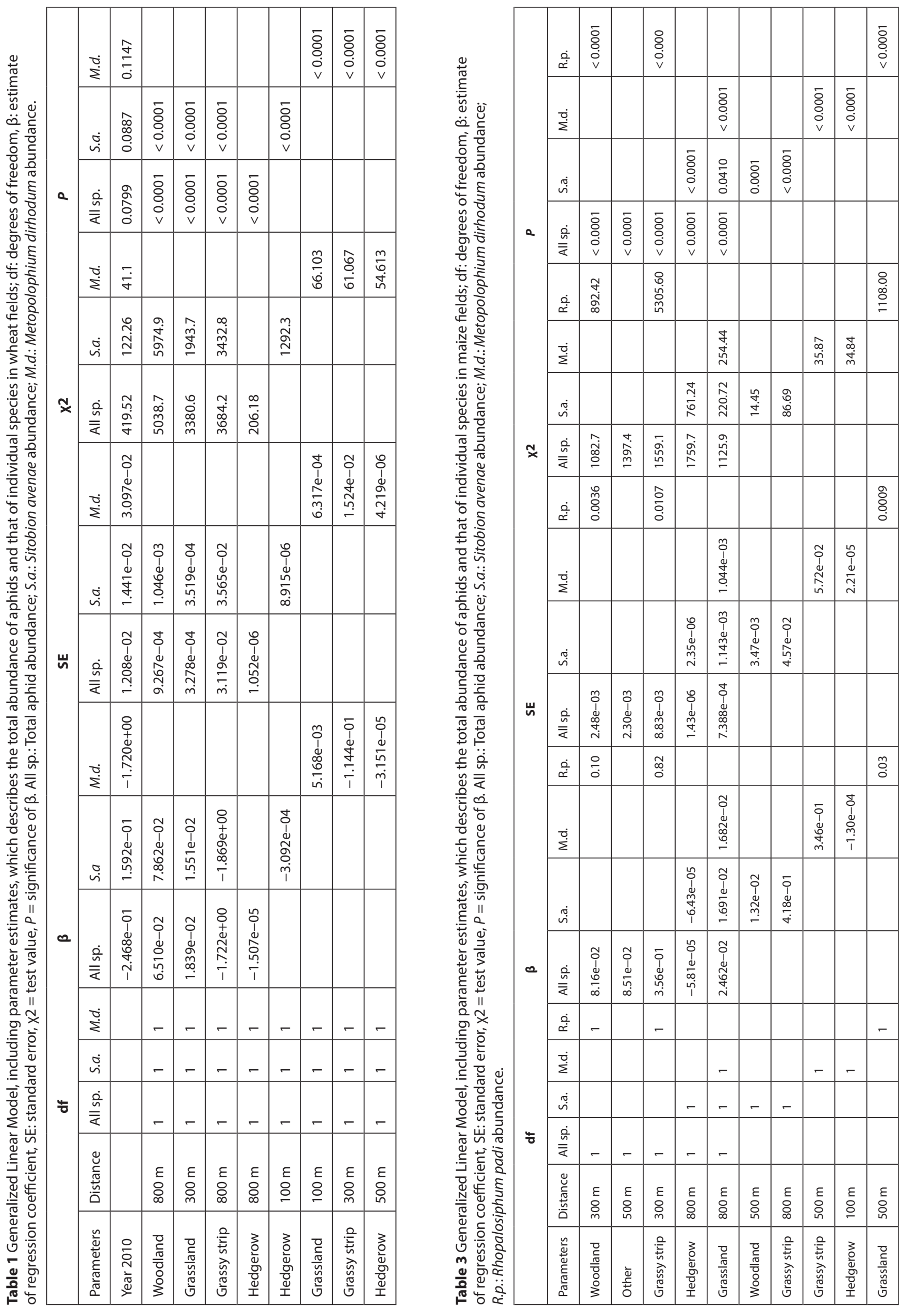


Table 2 Generalized Linear Model, including parameter estimates, which describes the total abundance and species richness of carabids in wheat fields; df: degrees of freedom, $\beta$ : estimate of regression coefficient; SE: standard error, $\mathrm{x} 2=$ test value, $P=$ significance of $\beta$.

\begin{tabular}{|l|l|l|l|l|l|l|l|l|l|l|l|}
\hline & \multicolumn{9}{|c|}{ Carabid abundance } & \multicolumn{3}{l|}{ Species richness of carabids } \\
\hline Parameters & Distance & $\mathbf{d f}$ & $\boldsymbol{\beta}$ & SE & $\mathbf{X}$ & $\mathbf{P}$ & $\mathbf{d f}$ & $\boldsymbol{\beta}$ & SE & $\mathbf{X 2}$ & $\boldsymbol{P}$ \\
\hline Year 2010 & & 1 & $7.009 \mathrm{e}-02$ & $1.019 \mathrm{e}-02$ & 47.363 & 0.0599 & & & & & \\
\hline Grassland & $800 \mathrm{~m}$ & 1 & $-6.148 \mathrm{e}-03$ & $6.315 \mathrm{e}-04$ & 94.165 & $<0.0001$ & & & & & \\
\hline Other & $300 \mathrm{~m}$ & 1 & $3.123 \mathrm{e}-02$ & $1.463 \mathrm{e}-03$ & 470.51 & $<0.0001$ & 1 & $-2.697 \mathrm{e}-02$ & $1.297 \mathrm{e}-02$ & 4.3555 & 0.05689 \\
\hline Grassy strip & $800 \mathrm{~m}$ & 1 & $6.010 \mathrm{e}-01$ & $2.019 \mathrm{e}-02$ & 853.46 & $<0.0001$ & 1 & & & & \\
\hline Hedgerow & $800 \mathrm{~m}$ & 1 & $-4.223 \mathrm{e}-06$ & $1.347 \mathrm{e}-06$ & 9.8548 & 0.001694 & 1 & $2.252 \mathrm{e}-05$ & $6.561 \mathrm{e}-06$ & 6.3529 & 0.001742 \\
\hline
\end{tabular}

Table 4 Generalized Linear Model, including parameter estimates, which describes the total abundance and species richness of carabids in maize fields; df: degrees of freedom, $\beta$ : estimate of regression coefficient; SE: standard error, $X^{2}=$ test value, $P=$ significance of $\beta$.

\begin{tabular}{|l|l|l|l|l|l|l|l|l|l|l|l|}
\hline & \multicolumn{5}{|c|}{ Carabid abundance } & \multicolumn{3}{l|}{ Species richness of carabids } \\
\hline Parameters & Distance & $\mathbf{d f}$ & $\boldsymbol{\beta}$ & SE & $\mathbf{X}$ & $\boldsymbol{P}$ & $\mathbf{d f}$ & $\boldsymbol{\beta}$ & SE & $\mathbf{X 2}$ & $\boldsymbol{P}$ \\
\hline Woodland & $100 \mathrm{~m}$ & 1 & $-8.945 \mathrm{e}-03$ & $2.228 \mathrm{e}-03$ & 16.18 & $<0.0001$ & & & & & \\
\hline Grassland & $100 \mathrm{~m}$ & 1 & $-4.128 \mathrm{e}-03$ & $4.277 \mathrm{e}-04$ & 93.81 & $<0.0001$ & & & & & \\
\hline Other & $500 \mathrm{~m}$ & & & & & & 1 & $-4.145 \mathrm{e}-02$ & $1.695 \mathrm{e}-02$ & 2.2793 & 0.05626 \\
\hline Grassy strip & $300 \mathrm{~m}$ & 1 & $2.402 \mathrm{e}-01$ & $1.087 \mathrm{e}-02$ & 522.18 & $<0.0001$ & & & & & \\
\hline Hedgerow & $800 \mathrm{~m}$ & & $-6.802 \mathrm{e}-05$ & $1.564 \mathrm{e}-06$ & 2043.40 & $<0.0001$ & 1 & $1.800 \mathrm{e}-05$ & $8.154 \mathrm{e}-06$ & 4.8647 & 0.02741 \\
\hline
\end{tabular}

$P=0.0001, \chi^{2}=86.69 ; \mathrm{df}=1, P<0.0001$, respectively). The association with grassland ${ }_{800}$ and grass strips ${ }_{500}$ was positive for $M$. dirhodum $(\chi 2=254.44 ; \mathrm{df}=1$, $P<0.0001, \chi^{2}=35.87 ; \mathrm{df}=1, P<0.0001$, respectively). The abundance of $R$. padi was significantly positively correlated with woodland ${ }_{300}$, grassy strip $_{300}$, and grassland $_{500}(\chi 2=892.42 ; \mathrm{df}=1, P<0.0001$, $\chi^{2}=5305.60 ; \mathrm{df}=1, P<0.0001, \chi^{2}=1108.00 ; \mathrm{df}=1$, $P<0.0001$, respectively). The total abundance of aphids, S. avenae and $M$. dirhodum were significantly negatively correlated with hedgerow ${ }_{800}$ and hedgerow ${ }_{100}$ $\left(\chi 2=1759.7 ; \mathrm{df}=1, P<0.0001, \chi^{2}=761.24 ; \mathrm{df}=3\right.$, $P<0.0001, \chi 2=34.84 ; \mathrm{df}=1, P<0.0001$, respectively).

The analysis revealed no spatial autocorrelation for the model residuals (GLM) of total aphid abundance at the level of the 12 fields sampled each year; aphids in 2009: $\mathrm{I}=-0.12, \mathrm{p}=0.13$; aphids in 2010: $\mathrm{I}=-0.21, \mathrm{p}=0.43$. This means that the residuals exhibit no spatial structure and the fields sampled can be considered as independent spatial replicates.

\section{The association between total abundance and species richness of carabids in maize fields and landscape}

The best model describing the total abundance of carabids included woodland ${ }_{100}$, grassland ${ }_{100}$, grass strips $_{300}$, and hedgerow ${ }_{800}$. The best model describing species richness of carabids included other ${ }_{500}$ and hedgerow ${ }_{800}-$ see AIC values of the generalized linear model, Appendix 4.
The best models for total abundance and species richness of carabid in maize fields are presented in Table 4; the total abundance of carabids is significantly negatively associated with woodland ${ }_{100}$, grassland ${ }_{100}$, and hedgerow ${ }_{800}(\chi 2=16.18 ; \mathrm{df}=1, P<0.0001$, $\chi^{2}=93.81 ; \mathrm{df}=3, P<0.0001, \chi^{2}=2043.40 ; \mathrm{df}=1$, $P<0.0001$, respectively). We found a significant positive correlation between the total abundance of carabids and grass strips $_{300}(\chi 2=522.18 ; \mathrm{df}=1, P<0.0001)$. The species richness of carabid was significantly positively correlated with hedgerow $_{800}(\chi 2=4.8647 ; \mathrm{df}=1, P=0.02741)$.

The analysis revealed no spatial autocorrelations in the residuals of the model (GLM) for carabid abundance at the level of the 12 fields sampled each year; carabids in 2009: $\mathrm{I}=0.11, \mathrm{p}=0.15$; carabids in 2010: $\mathrm{I}=0.23$, $\mathrm{p}=0.05$. This means that the residuals exhibit no spatial structure and the fields sampled can be considered as independent spatial replicates.

\section{Discussion}

\section{Association between abundance of aphids and landscape}

Composition of the landscape is associated with abundance of insect pest species in different ways (den Belder et al. 2002). For example, Bianchi et al. (2006) recently demonstrated that pest pressure recorded in more complex landscapes is lower in $45 \%$ and higher in $15 \%$ 
of the publications they reviewed. In our study, the abundance of aphids in the field was associated with landscape composition at a large scale $(500 \mathrm{~m}$ and $800 \mathrm{~m})$. There was a positive correlation between the abundance of the aphids and the proportion of woodland and grassland at these scales. Aphid abundance in wheat and maize field was negatively and positively, respectively, correlated with the proportion of grass strips. We also found that the abundance of aphids at these scales in both types of crop is negatively associated with the proportion of hedgerows.

The semi-natural habitats at a large scale are key factors in determining pest pressure (Rusch et al. 2010). In general, semi-natural habitats are more stable and so provide refuges for aphids from human disturbances (e.g., pesticides) and hibernation sites from which they can colonize crops in spring (Dixon 1973, 1985; Carter et al. 1982). Thus semi-natural habitats are sources and cereals sinks in aphid source-sink dynamics, as suggested by Dunning et al. (1992) and Dias (1996).

\section{Association between abundance and species richness of carabids and landscape}

There was a negative correlation between the abundance of carabids in wheat fields and the proportion of grassland and hedgerow at a large scale. There is a similar negative correlation for maize fields but with the proportion of grassland and woodland at a small scale. Carabid abundance was positively correlated with the proportion of grassy strips at a large scale in both types of crop. Carabid species richness was significantly positively correlated with the proportion of hedgerows at a large scale in both types of crop.

The semi-natural habitats promote the diversity of carabids, but their impacts on different species are debated (Holland 2002). Carabids are particularly sensitive to landscape structure, especially at a large scale (Holland 2002; Aviron et al. 2005). In our study, the relative proportions of semi-natural habitats such as woodland, grassland and hedgerows were negatively correlated with the abundance of carabids at two different scales. This may be because the dominant species in our study were Poecilus cupreus and Pterostichus melanarius (Fig. 2), which made up $71 \%$ of all the carabids captured. These species mainly occur in fields (Thiele 1977; Kromp 1999; Ameixa and Kindlmann 2008).

The proportion of hedgerows was positively correlated with species richness of carabids. This may be because hedgerows can be a habitat or a corridor for forest species (Petit and Burel 1998), which may venture into adjacent fields. Thus the carabid community in landscapes rich in hedgerows might have been enriched by species, which would not be present here if there were no hedgerows. Also the proportion of other elements was positively correlated with the abundance of aphids and carabids. This may be due to factors such as the presence of diversified resources and spread over time (e.g., flower of gardens) or a micro-climate (high temperatures in winter or spring).

\section{The association between the abundance of aphids and carabids and the proportion of the landscape under grass strips}

We found that the proportion of grassy strips was negatively correlated with the abundance of aphids in wheat fields, and positively in maize fields at different scales. Carabid abundance was positively correlated with the proportion of grass strips at large scales in both types of crop. Similarly, Collins et al. (2002) showed that there is a greater abundance of carabids in fields surrounded by grass strips, but their abundance decreased rapidly with distance from the strip. Pywell et al. (2011) show that grass strips promote abundances of predators. Carabids were more active and more abundant in fields bordered by grassy margins (Varchola and Dunn 2001; Hof and Bright 2010). Thus, even if it is not possible to draw any strong conclusions based on the results of our study, published data support the idea that grass strips may compensate for the loss of semi-natural habitats and the negative effect this has on beneficial insects, like carabids. This is particularly interesting since despite their cost, grass strips were not designed to be ecologically multifunctional: their initial - and only official - goal in France was to protect water against agricultural inputs (Delattre et al. 2011). However, some studies like Marshall et al. (2006) indicate that there are not more carabids in fields surrounded by $6 \mathrm{~m}$ wide uncultivated strips.

Grass strips have been a part of agricultural landscapes for many years, but their ecological role is still not fully understood (Marshall and Moonen 2002). Undoubtedly, they play an important role in increasing the amount of semi-permanent and semi-natural habitat in the landscape, thereby favouring beneficial species. They may thus partly compensate for the loss of semi-natural habitats and ameliorate the negative effects of the intensification of agriculture (Woodcock et al. 2010).

\section{Conclusions}

Because species differ in the scales at which they use resources and perceive their environment (Wiens 1989), studying the scale-dependent effect of local and landscape factors on pest abundance is a pre-requisite for conceiving ecologically-based pest management strategies at large scales. Our study demonstrated that the abundance of aphids and their natural carabid enemies was associated with the composition of the landscape at a large scale. We found a strong positive association between the abundance of the aphids and the proportion of woodland and grassland in the landscape. This result is supportive of Rusch et al. (2001) finding that semi-natural habitats at large scales have 
an important role in determining pest pressure. Thus, movement of aphids from semi-natural habitats into cereal crops can be considered as source-sink dynamics, as suggested by Dunning et al. (1992) and Dias (1996). Carabid abundance was negatively associated with the proportion of these semi-natural habitats. In our study, the carabid community was dominated by typical field species, which are known to be impeded by semi-natural habitat, such as dense hedgerows, which act as barriers and prevent dispersal. Carabids were more abundant in crop fields surrounded by grass strips while aphids showed a similar trend only in maize fields.

Further research is needed to clarify the relationships between the abundance of aphids and carabids and the composition of the landscape if we are to improve our ability to predict their dynamics in agricultural landscapes. This will help in the development of agroecosystems that are sustainable, conserve species diversity and maximize the service provided by natural enemies in controlling pest populations.

\section{Acknowledgements}

This study was funded by a grant from the ANR "Landscaphid" (French National Research Agency, ANR-09-STRA-05) for the LTER "Armorique" study area and two grants to PK: VOL/11/E036 of the GA CR, and CZ.1.05/1.1.00/02.0073 of the MSMT. Diab Al Hassan was funded by a PhD fellowship from the Syrian Minister of Higher Education. We thank Noémie Guillaud, Jessica Thevenot, Yann Rantier and Olivier Jambon who contributed to field work, data collection and/ or data analysis.

\section{REFERENCES}

Altieri MA (1999) The ecological role of biodiversity in agroecosystems. Agr Ecosyst Environ 74: 19-31.

Ameixa O, Kindlmann P (2008) Agricultural policy-induced landscape changes: effects on carabid abundance and their biocontrol potential. Eur J Entomol 105: 467-476.

Ameixa O, Kindlmann P (2011a) Biodiversity Drifts in Agricultural Landscapes Invertebrate Pest Control by Carabids. In: O Grillo and G Venora - Ecosystems Biodiversity InTech Publishers, Rijeka, Croatia, pp 315-332.

Ameixa O, Kindlmann P (2011b) Some exclusion cages do not exclude predators. Eur J Environ Sci 1: 67-69.

Andow DA (1991) Vegetational diversity and arthropod population response. Annu Rev Entomol 36: 561-586.

Arnold TW (2010) Uninformative Parameters and Model Selection Using Akaike's Information Criterion. J Wildlife Manage 74: $1175-1178$

Aviron S, Burel F, Baudry J, Schermann N (2005) Carabid assemblages in agricultural landcapes: impacts of habitat features landscape contexte at different spatial scales and farming intensity. Agr Ecosyst Environ 108: 205-217.
Baudry J, Bunce RGH, Burel F (2000) Hedgerows: An international perspective on their origin function and management. J Environ Manage 60: 7-22.

Baudry J, Schermann N, Boussard H (2006) Chloe 3.1: freeware of multi-scales analyses. INRA, SAD- Paysage.

Benton TG, Vickery JA, Wilson JD (2003) Farmland biodiversity: is habitat heterogeneity the key? Trends Ecol Evol 18: 182-188.

Bianchi FJJA, Booij CJH, Tscharntke T (2006) Sustainable pest regulation in agricultural landscapes: a review on landscape composition biodiversity and natural pest control. P Roy Soc Lond B Bio 273: 1715-1727.

Bouget C (2001) Echantillonnage des communautés de Coléoptères Carabiques en milieu forestier. Relation espèces-milieu et variations defficacité du piège à fosse. Symbioses NS4: 55-64.

Burel F, Baudry J (1995) Species biodiversity in changing agricultural landscapes: a case study in the Pays d'Auge France. Agr Ecosyst Environ 55: 193-200.

Burel F, Baudry J, Butet A, Clergeau P, Delettre Y, Le Cœur D, Dubs F, Morvan N, Paillat G, Petit S, Thenail C, Brunel E, Lefeuvre JC (1998) Comparative biodiversity along a gradient of agricultural landscapes. Acta Oecol 19: 47-60.

Burnham K, Anderson D (2002) Model Selection and Multimodel Inference: A Practical Information-Theoretic Approach. Springer Verlag.

Calcagno V, de Mazancourt C (2010) Glmulti: An R Package for Easy. Automated Model Selection with (Generalized) Linear Models. J Stat Softw 34: 1-29.

Carter N, Dixon AFG, Rabbinge R (1982) Cereal Aphid Populations, Biology, Simulation and Prediction. Pudoc, Wageningen, The Netherlands.

Christman MC (2008) Statistical modeling of observation data with spatial dependencies. J Wildl Manag 72: 22-33.

Collins KL, Boatman ND, Wilcox A, Holland JM, Chaney K (2002) Influence of beetles banks on cereal aphid predation in winter wheat. Agr Ecosyst Environ 93: 337-350.

Corbit M, Marks PL, Gardescu S (1999) Hedgerows as habitat corridors for forest herbs in central New York USA. J Ecol 87: 220-232.

Delattre T, Vernon P, Burel F (2011) An agri-environmental scheme enhances butterfly dispersal in European agricultural landscapes. Agr Ecosyst Environ. Available online 14 July 2011.

Den Belder E, Elderson J, Van Den Brink WJ, Schelling G (2002) Effect of woodlots on thrips density in leek fields: a landscape analysis. Agr Ecosyst Environ 91: 139-145.

Dias PC (1996) Sources and sinks in population biology. Trends Ecol Evol 11: 326-330.

Dixon AFG (1973) Aphid Biology. Edward Arnold Ltd., London, UK.

Dixon AFG (1985) Aphid Ecology. Chapman and Hall, Glasgow, UK.

Dixon AFG, Kindlmann P (1998) Population dynamics of aphids. In: Dempster JP, McLean IFG (eds) Insect populations in theory and in practice, Springer, Dordrecht, The Netherlands, pp 207-230.

Dixon AFG, Kindlmann P, Sequeira R (1996) Population regulation in aphids. In: Floyd RB, Sheppard AW, DeBarro PJ (eds) Frontiers of population ecology. CSIRO, Melbourne, Australia, pp 103-114.

Dunning JB, Danielson BJ, Pulliam HR (1992) Ecological processes that affect populations in complex landscapes. Oikos 65: $169-175$.

Fievet V, Dedryver CA, Plantegenest M, Simon JC, Outreman Y (2007) Aphid colony turn-over influences the spatial distribu- 
tion of the grain aphid Sitobion avenae over the wheat growing season. Agric For Entomol 9: 125-134.

Forsythe TG (2000) Ground Beetles. Natuarlist' Handbooks 8. Richmond Publishing, p 74.

Gardner B (1996) European Agriculture: Policies, Production and Trade, London: Routledge

Giordanengo P, Febvay G, Rahbé Y (2007) Comment les pucerons manipulent les plantes. Biofutur 279: 35-38.

Grez AA, Zaviezo T, Diaz S, Camousseight B, Cortes G (2008) Effects of habitat loss and fragmentation on the abundance and species richness of aphidophagous beetles and aphids in experimental alfalfa landscapes. Eur J Entomol 105: 411-420.

Hill DS (1987) Agricultural Insect Pests of Temperate Regions and their Control. Cambridge University Press, Cambridge, UK.

Hof AR, Bright PW (2010) The impact of grassy field margins on macro-invertebrate abundance in adjacent arable fields. Agr Ecosyst Environ 139: 280-283.

Holland JM (2002) The agroecology of carabid beetles. Andover. Intercept.

Hulle M, Coeur d'Acier A, Bankhead-Dronnet S, Harrington R (2010) Aphids in the face of global changes. C R Biol 333: 497503.

Keller I, Largiadèr CR (2003) Recent habitat fragmentation caused by major roads leads to reduction of gene flow and loss of genetic variability in ground beetles. P R Soc London 270: 417-423.

Kindlmann P, Aviron S, Burel F (2005) When is landscape matrix important for determining animal fluxes between resource patches? Ecol Complex 2: 150-158.

Kindlmann P, Dixon AFG (1999) Strategies of aphidophagous predators: lessons for modelling insect predator-prey dynamics. J Appl Entomol 123: 397-399.

Kindlmann P, Růžička Z (1992) Possible consequences of a specific interaction between predators and parasites of aphids. Ecol Model 61: 253-265.

Krauss J, Gallenberger I, Steffan-Dewenter I (2011) Decreased functional diversity and biological pest control in conventional compared to organic crop fields. PloS One 6: e19502.

Krebs JR, Wilson JD, Bradbury RB, Siriwardena GM (1999) The second silent spring? Nature 400: 611-612.

Kromp B (1999) Carabid beetles in sustainable agriculture: a review on pest control efficacy, cultivation impacts and enhancement. Agr Ecosyst Environ 74: 187-228.

Le Coeur D, Baudry J, Burel F (1997) Field margins plant assemblages: variation partitioning between local and landscape factors. Landscape Urban Plan 37: 57-71.

Lee JC, Heimpel GE, Leibee GL (2004) Comparing floral nectar and aphid honeydew diets on the longevity and nutrient levels of a parasitoid wasp. Entomol Exp Appl 111: 189-199.

Legendre P (1993) Spatial autocorrelation: trouble or new paradigm? Ecology 74: 1659-1673.

Levie A, Legrand MA, Dogot P, Pels C, Baret PV, Hance T (2005) Mass releases of Aphidius rhopalosiphi (Hymenoptera: Aphidiinae) and strip management to control of wheat aphids. Agr Ecosyst Environ 105: 17-21.

Lewis WJ, van Lenteren JC, Phatak SC, Tumlinson JH (1997) A total system approach to sustainable pest management. Proc Natl Acad Sci USA 94: 12243-12248.

Maisonhaute JE, Lucas E (2011) Influence of landscape structure on the functional groups of an aphidophagous guild: Active-searching predators, furtive predators and parasitoids. Eur J Environ Sci 1: 41-50.
Marshall EJP, Moonen AC (2002) Field margins in northern Europe: their functions and interactions with agriculture. Agr Ecosyst Environ 89: 5-21.

Marshall EJP, West TM, Kleijn D (2006) Impacts of an agri-environment field margin prescription on the flora and fauna of arable farmland in different landscapes. Agr Ecosyst Environ 113: $36-44$

Martinez JJI, Mokady O, Wool D (2005) Patch size and patch quality of gall-inducing aphids in a mosaic landscape in Israel. Landscape Ecol 20: 1013-1024.

Nault L R (1997) Arthropod transmission of plant viruses: a new synthesis. Ann Entomol Soc Am 90: 521-541.

Oerke EC (2006) Crop losses to pests. J Agr Sci 144: 31-43.

Oerke EC, Dehne HW (2004) Safeguarding production-losses in major crops and the role of crop protection. Crop Prot 23: 275-285.

Östman Ö, Ekbom B, Bengtsson J (2001) Landscape heterogeneity and farming practice influence biological control. Basic Appl Ecol 2: 365-371.

Petit S, Burel F (1998) Effects of landscape dynamics on the metapopulation of a ground beetle (Coleoptera Carabidae) in a hedgerow network. Agr Ecosyst Environ 69: 243-252.

Plantegenest M, Le May C, Fabre F (2007) Landscape epidemiology of plant diseases. J R Soc Interface 4: 963-972.

Plantegenest M, Pierre JS, Dedryver CA, Kindlmann P (2001) Assessment of the relative impact of different natural enemies on population dynamics of the grain aphid Sitobion avenae in the field. Ecol Ent 26: 404-410.

Pywell RF, Meek WR, Loxton RG, Nowakowski M, Carvell C, Woodcock BA (2011) Ecological restoration on farmland can drive beneficial functional responses in plant and invertebrate communities. Agr Ecosyst Environ 140: 62-67.

Rand T A, Tscharntke T (2007) Contrasting effects of natural habitat loss on generalist and specialist aphid natural enemies. Oikos 116: 1353-1362.

R-Development-Core-Team (2008) R: a language and environment for statistical computing. R Foundation for Statistical Computing, Vienna, Austria.

Ricci B, Franck P, Toubon JF, Bouvier JC, Sauphanor B, Lavigne C (2009) The influence of landscape on insect pest dynamics: a case study in southeastern France. Landscape Ecol 24: 337-349.

Robinson RA, Sutherland WJ (2002) Post-war changes in arable farming and biodiversity in Great Britain. J Appl Ecol 39: 157-176.

Rosenberg MS (2009) Passage: Pattern Analysis, Spatial Statitics and Geographic Exegesis. Arizona State University, Tempe, AZ.

Rusch A, Valantin-Morison M, Sarthou JP, Roger-Estrade J (2010) Biological control of insect pests in agroecosystems: effects of crop management farming systems and semi-natural habitats at the landscape scale. A review. Adv Agron. Doi: 10.1016/S0065 -2113(10)09006-1.

Šipoš J, Kvastegård E, Baffoe KO, Sharmin K, Glinwood R, Kindlmann P (2012) Differences in the predatory behaviour of male and female ladybird beetles (Coccinellidae). Eur J Environ Sci 2: 51-55.

Stoate C, Boatman ND, Borralho RJ, Carvalho CR, de Snoo GR, Eden P (2001) Ecological impacts of arable intensification in Europe. J Environ Manage 63: 337-365.

Sunderland KD (2003) Invertebrate Pest Control by Carabids. In: Holland JM (ed) The Agroecology of Carabid Beetles. Intercept Publishers, Hampshire, UK, pp 165-214. 
Symondson WOC, Sunderland KD, Greenstone MH (2002) Can generalist predators be effective biocontrol agents? Annu Rev Entomol 47: 561-594.

Thébaud G, Sauvion N, Chadoeuf J, Dufils A, Labonne G (2006) Identifying Risk Factors for European Stone Fruit Yellows from a Survey. Phytopathology 96: 890-899.

Thiele HU (1977) Carabid beetles in their environments: A study on habitat selection by adaptations in physiology and behaviour. Zoophysiology and Ecology: 10. Springer-Verlag, Berlin.

Thornton DH, Branch LC, Sunquist ME (2011) The influence of landscape patch and within-patch factors on species presence and abundance: a review of focal patch studies. Landscape Ecol 26: 7-18.

Trautner J, Geigenmüller K (1987) Tiger beetles, ground beetles, illustrated key to the Cicindelidae and Carabidae of Europe. J. Margraf, Aichtal, Allemagne.

van Emden HF, Harrington R (2007) Aphids as Crop Pests. CABI Wallingford, Oxford, UK, pp 447-468.

Vanbergen AJ, Woodcock BA, Koivula M et al. (2010) Trophic level modulates carabid beetle responses to habitat and landscape structure: a pan-European study. Ecol Entomol 35: 226-235.
Vandewalle M, Debello F, Berg MP et al. (2010) Functional traits as indicators of biodiversity response to land use changes across ecosystems and organisms. Biodivers Conserv 19: 2921-2947.

Varchola JM, Dunn JP (2001) Influence of hedgerow and grassy field borders on ground beetle (Coleoptera : Carabidae) activity in fields of corn. Agr Ecosyst Environ 83: 153-163.

Wilson C, Tisdell C (2001) Why farmers continue to use pesticides despite environmental health and sustainability costs? Ecol Econ 39: 449-462.

Winder L, Perry JN, Holland JM (1999) The spatial and temporal distribution of the grain aphid Sitobion avenae in winter wheat. Entomol Exp Appl 93: 275-288.

Woodcock BA, Redhead J, Vanbergen AJ, Hulmes L, Hulmes S, Peyton J, Nowakowski M, Pywell RF, Heard MS (2010) Impact of habitat type and landscape structure on biomass species richness and functional diversity of ground beetles. Agr Ecosyst Environ 139: 181-186.

Wratten SD, Bowie MH, Hickman JM, Evans AM, Sedcole JR, Tylianakis JM (2003) Field boundaries as barriers to movement of hover flies (Diptera: Syrphidae) in cultivated land. Oecologia 134: 605-611. 
Appendix 1 Comparison of AIC (Akaike Information Criterion) values of the four best generalized linear models of total and aphid species abundances in wheat fields. Best models are in bold.

\begin{tabular}{|c|c|c|c|c|c|}
\hline \multicolumn{6}{|c|}{ Total aphid abundance } \\
\hline Parameters & Distance & Model1 & Model2 & Model3 & Null model \\
\hline Year 2010 & & $x$ & $x$ & & \\
\hline Woodland & $800 \mathrm{~m}$ & $x$ & $x$ & $x$ & \\
\hline Grassland & $300 \mathrm{~m}$ & $\times$ & $x$ & $x$ & \\
\hline Grassy strip & $800 \mathrm{~m}$ & $x$ & $x$ & $x$ & \\
\hline Hedgerow & $800 \mathrm{~m}$ & $x$ & $x$ & $x$ & \\
\hline Other & $500 \mathrm{~m}$ & & $x$ & $x$ & \\
\hline (AIC) & & 5164.7 & 5568.9 & 5782.3 & 31420 \\
\hline \multicolumn{6}{|c|}{ Sitobion avenae abundance } \\
\hline Year 2010 & & $\times$ & & & \\
\hline Woodland & $800 \mathrm{~m}$ & $x$ & $x$ & $x$ & \\
\hline Grassland & $300 \mathrm{~m}$ & $\times$ & $\times$ & $\times$ & \\
\hline Grassy strip & $800 \mathrm{~m}$ & $\times$ & $\times$ & $x$ & \\
\hline Hedgerow & $100 \mathrm{~m}$ & $x$ & $x$ & $x$ & \\
\hline Other & $800 \mathrm{~m}$ & & $x$ & $x$ & \\
\hline (AIC) & & 4102.9 & 4423.2 & 5493.2 & 35927 \\
\hline \multicolumn{6}{|c|}{ Metopolophium dirhodum abundance } \\
\hline Year 2010 & & $\times$ & $x$ & & \\
\hline Woodland & $500 \mathrm{~m}$ & & $x$ & $x$ & \\
\hline Grassland & $100 \mathrm{~m}$ & $\times$ & $x$ & $x$ & \\
\hline Grassy strip & $300 \mathrm{~m}$ & $\times$ & $x$ & $x$ & \\
\hline Hedgerow & $500 \mathrm{~m}$ & $x$ & $x$ & & \\
\hline (AIC) & & 1360.0 & 1365.3 & 1413.3 & 6095 \\
\hline
\end{tabular}

Appendix 2 Comparison of AIC (Akaike Information Criterion) values of the four best generalized linear models of total and species richness of carabids in wheat fields. Best models are in bold.

\begin{tabular}{|c|c|c|c|c|c|}
\hline \multicolumn{6}{|c|}{ Carabid abundance } \\
\hline Parameters & Distance & Model1 & Model2 & Model3 & Null model \\
\hline Year 2010 & & $x$ & $x$ & $x$ & \\
\hline Grassland & $800 \mathrm{~m}$ & $x$ & $x$ & $x$ & \\
\hline Other & $300 \mathrm{~m}$ & $x$ & $x$ & $x$ & \\
\hline Grassy strip & $800 \mathrm{~m}$ & $x$ & $x$ & $x$ & \\
\hline Hedgerow & $800 \mathrm{~m}$ & $x$ & $x$ & & \\
\hline Woodland & $100 \mathrm{~m}$ & & $x$ & & \\
\hline (AIC) & & 12305 & 12317 & 12325 & 14877 \\
\hline \multicolumn{6}{|c|}{ Species richness of carabids } \\
\hline Grassland & $500 \mathrm{~m}$ & & $x$ & & \\
\hline Grassy strip & $300 \mathrm{~m}$ & & $x$ & $x$ & \\
\hline Hedgerow & $800 \mathrm{~m}$ & $x$ & $x$ & $x$ & \\
\hline Other & $300 \mathrm{~m}$ & $x$ & & & \\
\hline (AIC) & & 147.64 & 150.55 & 158.5 & 155 \\
\hline
\end{tabular}


Appendix 3 Comparison of AIC (Akaike Information Criterion) values of the four best generalized linear models of total and aphid species abundances in maize fields. Best models are in bold.

\begin{tabular}{|c|c|c|c|c|c|}
\hline \multicolumn{6}{|c|}{ Total aphid abundance } \\
\hline Parameters & Distance & Model1 & Model2 & Model3 & Null model \\
\hline Year 2010 & & & $\times$ & $\times$ & \\
\hline Woodland & $300 \mathrm{~m}$ & $x$ & $x$ & & \\
\hline Other & $500 \mathrm{~m}$ & $\times$ & $x$ & $x$ & \\
\hline Grassy strip & $300 \mathrm{~m}$ & $x$ & $x$ & $x$ & \\
\hline Hedgerow & $800 \mathrm{~m}$ & $x$ & $x$ & $x$ & \\
\hline Grassland & $800 \mathrm{~m}$ & $x$ & $x$ & $x$ & \\
\hline (AIC) & & 4759.5 & 4765.2 & 5718.3 & 14475 \\
\hline \multicolumn{6}{|c|}{ Sitobion avenae abundance } \\
\hline Year 2010 & & & $x$ & $x$ & \\
\hline Hedgerow & $800 \mathrm{~m}$ & $x$ & $x$ & $x$ & \\
\hline Grassland & $800 \mathrm{~m}$ & $x$ & $x$ & $x$ & \\
\hline Woodland & $500 \mathrm{~m}$ & $x$ & $x$ & & \\
\hline Grassy strip & $800 \mathrm{~m}$ & $x$ & & $x$ & \\
\hline Other & $800 \mathrm{~m}$ & & $\times$ & $\times$ & \\
\hline$(\mathrm{AIC})$ & & 1613.7 & 1620.7 & 1631.8 & 7931 \\
\hline \multicolumn{6}{|c|}{ Metopolophium dirhodum abundance } \\
\hline Year 2010 & & & $x$ & & \\
\hline Woodland & $300 \mathrm{~m}$ & & $\times$ & $x$ & \\
\hline Grassland & $800 \mathrm{~m}$ & $x$ & $x$ & & \\
\hline Grassy strip & $500 \mathrm{~m}$ & $x$ & $x$ & $x$ & \\
\hline Hedgerow & $100 \mathrm{~m}$ & $x$ & $x$ & $x$ & \\
\hline Other & $800 \mathrm{~m}$ & & & $x$ & \\
\hline (AIC) & & 783.22 & 798.46 & 805.76 & 1455.333 \\
\hline \multicolumn{6}{|c|}{ Rhopalosiphum padi abundance } \\
\hline Year 2010 & & & $\times$ & $x$ & \\
\hline Woodland & $300 \mathrm{~m}$ & $\times$ & $x$ & $x$ & \\
\hline Grassy strip & $300 \mathrm{~m}$ & $x$ & $x$ & $x$ & \\
\hline Grassland & $500 \mathrm{~m}$ & $x$ & $x$ & & \\
\hline Hedgerow & $800 \mathrm{~m}$ & & & $x$ & \\
\hline Other & $800 \mathrm{~m}$ & & $x$ & $x$ & \\
\hline (AIC) & & 8107.1 & 8171.9 & 8268.8 & 19013.92 \\
\hline
\end{tabular}

Appendix 4 Comparison of AIC (Akaike Information Criterion) values of the four best generalized linear models of total and species richness of carabids in maize fields. Best models are in bold.

\begin{tabular}{|c|c|c|c|c|c|}
\hline \multicolumn{6}{|c|}{ Carabid abundance } \\
\hline Parameters & Distance & Model1 & Model2 & Model3 & Null model \\
\hline Year 2010 & & & & $x$ & \\
\hline Woodland & $100 \mathrm{~m}$ & $x$ & $x$ & $x$ & \\
\hline Grassland & $100 \mathrm{~m}$ & $x$ & $x$ & $x$ & \\
\hline Other & $500 \mathrm{~m}$ & & $x$ & $x$ & \\
\hline Grassy strip & $300 \mathrm{~m}$ & $x$ & & & \\
\hline Hedgerow & $800 \mathrm{~m}$ & $x$ & $x$ & $x$ & \\
\hline (AIC) & & 6234.9 & 6305.1 & 6386.5 & 12852 \\
\hline \multicolumn{6}{|c|}{ Species richness of carabids } \\
\hline Woodland & $300 \mathrm{~m}$ & & $x$ & $x$ & \\
\hline Hedgerow & $800 \mathrm{~m}$ & $x$ & $x$ & $x$ & \\
\hline Other & $500 \mathrm{~m}$ & $x$ & & $\times$ & \\
\hline (AIC) & & 139.29 & 143.3 & 143.3 & 143 \\
\hline
\end{tabular}

